\title{
Gloriosa superba Mediated Synthesis of Silver and Gold Nanoparticles for Anticancer Applications
}

Sougata Ghosh ${ }^{1,2 *}$, Ashwini N. Harke', Maliyackal Jini Chacko', Sonal P. Gurav'1, Komal A. Joshi², Aarti Dhepe ${ }^{2}$, Ankush Dewle ${ }^{2}$, Geetanjali B. Tomar $^{2}$, Rohini Kitture ${ }^{3}$, Vijay Singh Parihar ${ }^{4}$, Kaushik Banerjee ${ }^{5}$, Narayan Kamble ${ }^{5}$, Jayesh Bellare ${ }^{6}$, and Balu A. Chopade ${ }^{1,7}$

${ }^{1}$ Department of Microbiology, Modern College of Arts, Science and Commerce, Ganeshkhind, Pune-411016, India

${ }^{2}$ Institute of Bioinformatics and Biotechnology, University of Pune, Pune-411007, India

${ }^{3}$ Department of Applied Physics, Defense Institute of Advanced Technology, Girinagar, Pune-411025, India

${ }^{4}$ Garware Research Centre, Department of Chemistry, University of Pune, Pune-411007, India

${ }^{5}$ National Referral Laboratory, ICAR-National Research Centre for Grapes, Manjri Farm, Pune 412 307, India

${ }^{6}$ Department of Chemical Engineering, Indian Institute of Technology, Bombay, Powai, Mumbai-400076, India

${ }^{7}$ Department of Microbiology, University of Pune, Pune-411007, India

\begin{abstract}
Designing of novel environmentally benign route for synthesis of nanoparticles is a prerequisite for developing nanomedicine. Medicinal plants serve as rich source of diverse phytochemicals which not only synthesize but also stabilize the bioreduced nanoparticles. Herein we report for the first time the anticancer activity of gold and silver nanoparticles synthesized employing Gloriosa superba tuber extract (GSTE). The synthesis was found to be rapid and efficient which completed within $5 \mathrm{~h}$. Optimum concentration of $\mathrm{AgNO}_{3}$ was found to be $3 \mathrm{mM}$ for synthesis of AgNPs while for AuNPs it was found to be $4 \mathrm{mM}$. Higher temperature facilitated the biosynthesis process, optimum being $50^{\circ} \mathrm{C}$. High resolution transmission electron microscopy revealed that the AgNPs were smaller in a range from 3 to 20 $\mathrm{nm}$, majority being spherical in shape. AuNPs were of exotic shapes like spheres, triangles and hexagons that varied in size from 20 to $120 \mathrm{~nm}$. Elemental gold and silver were confirmed in the AuNPs and AgNPs, respectively using energy dispersive spectroscopy and X-ray diffraction spectroscopy. Fourier transform infrared spectroscopy indicated a broad peak from 3300 to $3500 \mathrm{~cm}^{-1}$ in all the three spectra that was attributed to O-H group of phenols/alcohol, which could be a component of the GSTE that might play a critical role in synthesis and stabilization. Biochemical analysis showed the presence of phenolics, starch, reducing sugars, ascorbic acid and citric acid. Gas chromatography-mass spectroscopy indicated that the most predominant compounds found in GSTE, were phenol, 3-methoxy- $\left(\mathrm{C}_{7} \mathrm{H}_{8} \mathrm{O}_{2}\right)$, salicyl alcohol $\left(\mathrm{C}_{7} \mathrm{H}_{8} \mathrm{O}_{2}\right)$, benzoic acid, 2-hydroxy-6-methoxy- $\left(\mathrm{C}_{8} \mathrm{H}_{8} \mathrm{O}_{4}\right)$ and asarone $\left(\mathrm{C}_{12} \mathrm{H}_{16} \mathrm{O}_{3}\right)$. AgNPs exhibited 42.04 $\pm 1.87 \%$ anticancer activity while AuNPs showed only $35.59 \pm 4.1 \%$. A synergistic antiproliferative activity up to $58.48 \pm$ $1.71 \%$ was observed on combination of both which was confirmed by flow cytometry and confocal microscopy.
\end{abstract}

Keywords: Gloriosa superba tuber extract; Gold nanoparticles; Silver nanoparticles; Synergy; Anticancer activity

\section{Introduction}

Nanomedicine is one of the emerging areas of nanotechnology research owing to its attractive therapeutic properties in various medical applications. Nanoparticulate materials exhibit larger surface area, unique electrical, magnetic, optical and chemical properties unlike the bulk metals [1]. Nanosilver is widely used in cosmetics, textiles, antimicrobial coatings, pastes, water purifiers and electronics. At the same time colloidal silver is used to treat tonsillitis, ulcers, infections, sepsis and burns. Silver nanoparticles (AgNPs) are well known for its antifungal, antiviral, antibacterial and anti-angiogenesis properties as well [2]. Similarly, gold has also been used in treatment of psoriasis, inflammations, pemphigus, discoid lupus erythematosus, drug delivery and tumor imaging [3]. Chemical synthesis of metal nanoparticles involving UV irradiation, laser ablation, plasma synthesis, Turkevich method, wet chemical synthesis, chemical reduction pyrolysis, lithography, chemical vapour deposition, sol-gel technique and electrodeposition involve toxic and hazardous chemicals that pose threat to the environment as well as compromises the biocompatibility of the nanoparticles. Hereby, there is a growing need for development of environmentally benign, rapid and efficient biological route for synthesis of novel metal nanoparticles with enhanced therapeutic potential. Recently, various medicinal plants, fungi and bacteria are being explored for their ability to synthesize metal nanoparticles [4-16].

Gloriosa superba is one of the comparatively less explored traditional medicinal plant that has immense application as a herbal remedy.
Lower doses of superbine and gloriosine found in G. superba tubers are used as purgative, tonic and antiabortive. White tuber powder mixed with honey is used as a traditional and complementary alternative medicine to treat gonorrhea, leprosy, colic, intestinal worms, for promoting labour pains and application over the suprapubic region and vagina. Local application of its warm poultice helps to treat rheumatism and neuralgic pains. Colchicine, a predominant bioactive compound present in it is used in the treatment of gout [17]. However till date there are no reports of the therapeutic applications of the nanoparticles synthesized using this plant extract. Out of our growing interest in the field of nanobiotechnology we tried to add one more attribute to its application for considering it as a model system in nanobiotechnology.

In view of this background, herein we report for the first time the anticancer activity of silver (AgNPs) and gold nanoparticles (AuNPs) synthesized by Gloriosa superba tuber extract (GSTE).

*Corresponding author: Sougata Ghosh, Department of Microbiology, Modern College of Arts, Science and Commerce, Ganeshkhind, Pune 411016, India, Tel: 9923268332; E-mail: ghoshsibb@gmail.com

Received July 18, 2016; Accepted August 03, 2016; Published August 11, 2016 Citation: Ghosh S, Harke AN, Chacko MJ, Gurav SP, Joshi KA, et al. (2016) Gloriosa superba Mediated Synthesis of Silver and Gold Nanoparticles for Anticancer Applications. J Nanomed Nanotechnol 7: 390. doi: 10.4172/2157 7439.1000390

Copyright: $\odot 2016$ Ghosh S, et al. This is an open-access article distributed under the terms of the Creative Commons Attribution License, which permits unrestricted use, distribution, and reproduction in any medium, provided the original author and source are credited. 
Citation: Ghosh S, Harke AN, Chacko MJ, Gurav SP, Joshi KA, et al. (2016) Gloriosa superba Mediated Synthesis of Silver and Gold Nanoparticles for Anticancer Applications. J Nanomed Nanotechnol 7: 390. doi: 10.4172/2157-7439.1000390

\section{Materials and Methods}

\section{Plant material and preparation of extract}

G. superba tubers were collected from Western Ghats of Maharashtra, India. Tubers were chopped into thin slices, and dried for 2-3 days at room temperature followed by grinding into fine powder. G. superba tuber extract (GSTE) was prepared by adding $5 \mathrm{~g}$ of finely ground tuber powder into a $250 \mathrm{~mL}$ conical flask containing $100 \mathrm{~mL}$ distilled water. The mixture was boiled for $5 \mathrm{~min}$ and then decanted followed by centrifugation at $3000 \mathrm{rpm}$ for 10 minutes, and filtration through Whatman No.1 filter paper. The filtrate was collected and stored at $40^{\circ} \mathrm{C}$ for further use [6].

\section{Synthesis and characterization of silver and gold nanoparticles}

Synthesis of AgNPs employing GSTE was initiated by addition of $5 \mathrm{~mL}$ of GSTE into $95 \mathrm{~mL}$ of $1 \mathrm{mM} \mathrm{AgNO}_{3}$ solution. The mixture was incubated at $40^{\circ} \mathrm{C}$ for $5 \mathrm{~h}$ in a shaking incubator. Bioreduction of $\mathrm{Ag}^{+}$ions was confirmed by recording the ultraviolet-visible spectra at regular intervals on a spectrophotometer (SpectraMax Molecular Devices Corporation, Sunnyvale, CA) operating at a resolution of $1 \mathrm{~nm}$. Similarly for synthesis of gold nanoparticles $5 \mathrm{~mL}$ of GSTE was added into $95 \mathrm{~mL}$ of $1 \mathrm{mM} \mathrm{HAuCl}_{4}$ solution. The effect of temperature on the rate of synthesis was checked by carrying out the reaction in a water bath at $4^{\circ} \mathrm{C}-50^{\circ} \mathrm{C}$ with reflux. Concentration optimization studies were carried out by monitoring the reaction rate varying the respective salt concentration from 0.3 to $5 \mathrm{mM}$. The bioreduced nanoparticles were characterized using high resolution transmission electron microscopy (HRTEM), energy dispersive spectroscopy (EDS), X-ray diffraction (XRD) and fourier transform infrared spectroscopy (FTIR) as per our earlier reports [5].

\section{Phytochemicals analysis}

Total phenolic, flavonoid, starch, reducing sugar, ascorbic acid and citric acid content of the GSTE were determined using biochemical assays as per our earlier report [6].

\section{GC-MS/MS analysis}

The analysis of GSTE was carried out with Agilent GC (7890A) equipped with a CTC Combipal (CTC Analytics, Switzerland) autosampler, connected to a triple quadrupole mass spectrometer (7000B, Agilent Technologies, Santa Clara, USA). The system was controlled using MassHunter software (ver B.05.00.412). The analytical separation was performed using HP-5MS $(30 \mathrm{~m} \times 0.25 \mathrm{~mm}, 0.25$ $\mathrm{mm})$ capillary column. A gooseneck liner $(78.5 \mathrm{~mm} \times 6.5 \mathrm{~mm}, 4 \mathrm{~mm})$ from Agilent Technologies (Santa Clara, USA) was used. The carrier gas (Helium) flow was set at a constant rate of $1.0 \mathrm{~mL} / \mathrm{min}$. The oven temperature program was set as follows: initial temperature of $60^{\circ} \mathrm{C}(3$ min hold), ramped to $300^{\circ} \mathrm{C}$ at $4^{\circ} \mathrm{C} / \mathrm{min}(0 \mathrm{~min}$ hold $)$ resulting in a total run time of $63 \mathrm{~min}$. The transfer line temperature was maintained at $285^{\circ} \mathrm{C}$. The multi-mode inlet (MMI) was operated in pulsed splitless mode and $2 \mu \mathrm{L}$ of the sample was injected. Splitless program was set at the initial temperature of $60^{\circ} \mathrm{C}(1 \mathrm{~min}$ hold $)$, raised to $200^{\circ} \mathrm{C}$ at $50^{\circ} \mathrm{C} /$ min $(2 \mathrm{~min} \mathrm{hold})$, then $300^{\circ} \mathrm{C}$ at $100^{\circ} \mathrm{C} / \mathrm{min}(1 \mathrm{~min}$ hold $)$ and finally raised to $350^{\circ} \mathrm{C}$ at $600^{\circ} \mathrm{C} / \mathrm{min}$ ( $1 \mathrm{~min}$ hold). The purge flow to split vent was maintained at $50 \mathrm{~mL} / \mathrm{min}$, at a pressure of 25 psi at $0.5 \mathrm{~min}$ after injection. The mass spectrometer was operated in Scan mode with acquisition starting at $4.1 \mathrm{~min}$. Electron impact ionization (EI+) was achieved at $70 \mathrm{eV}$ and the ion source temperature was set at $280^{\circ} \mathrm{C}$.

\section{Cell toxicity assay}

Antiproliferative activities of AgNPs and AuNPs synthesized by GSTE individually as well as together were evaluated against MCF-7 cells employing 3-(4,5-dimethyl-thiazol-2-yl)-2,5-diphenyltetrazolium bromide (MTT) assay as per our earlier report [4]. In short, MCF-7 cell line (human breast adenocarcinoma cells) was obtained from National Centre for Cell Science, Pune, India and cultured in Dulbecco's Modified Eagle Medium (DMEM), supplemented with $10 \%$ fetal bovine serum, streptomycin $(100 \mathrm{~g} / \mathrm{mL})$ and penicillin $(100 \mathrm{U} / \mathrm{mL})$ and were maintained in a humidified atmosphere at $37^{\circ} \mathrm{C}$ and $5 \% \mathrm{CO}_{2} .4$ $\times 10^{4}$ cells were seeded per well in a 96-well plate and allowed to adhere by incubation for $24 \mathrm{~h}$ followed by addition of nanoparticles to the cells at a concentration of $10 \mu \mathrm{g} / \mathrm{mL}$. After $48 \mathrm{~h}$, media was removed and the cells were washed with PBS. MTT solution $(0.5 \mathrm{mg} / \mathrm{ml})$ was added to the wells and incubated for $2 \mathrm{~h}$. Thereafter, formazan crystals were dissolved using acidified isopropanol and the absorbance was measured at $570 \mathrm{~nm}$ on a microplate reader (SpectraMax M5, Molecular Devices Corporation, Sunnyvale, CA).

\section{Flow cytometric analysis}

Flow cytometric analysis after treatment with respective nanoparticles and their combination was carried out in order to confirm apoptosis as the most predominant mechanism behind the antiproliferative activity. $5 \times 10^{5}$ cells were seeded in a T-25 flask and incubated for $24 \mathrm{~h}$ followed by treatment with AgNPs, AuNPs and combination of both at a concentration of $10 \mu \mathrm{g} / \mathrm{mL}$. After $48 \mathrm{~h}$ of incubation the cells were harvested and stained with Annexin-V-FITC and propidium iodide (PI) at a dilution of $1: 20$, for $10-15 \mathrm{~min}$ at $4^{\circ} \mathrm{C}$ These were then acquired in BD FACS Callibur and analysed using Cell Quest Pro software [4].

\section{Confocal microscopy}

MCF-7 cells were seeded on to glass cover slips at a density of $5 \times 10^{4}$ cells followed by $24 \mathrm{~h}$ of incubation at $37^{\circ} \mathrm{C}$ for adherence. Thereafter the cells were treated as per the above protocol. Treated cells were stained with AnnexinV(AV)-FITC and PI, both at a dilution of 1:20 for $15 \mathrm{~min}$ at $4^{\circ} \mathrm{C}$ and were fixed in $4 \%$ para-formaldehyde (PFA) followed by observation under LSM 780 confocal laser scanning microscope, Carl Zeiss (Magnification 40x) [4].

\section{Results}

\section{Synthesis and characterization}

Synthesis of AgNPs was confirmed by the development of brown color on addition of GSTE in $\mathrm{AgNO}_{3}$ solution. The color change was visible after $30 \mathrm{~min}$ of incubation which gradually became intense on incubation till 5 h. Further, the UV-visible spectra as well confirmed the synthesis which marked an increase in the peak intensity at 460 $\mathrm{nm}$ (Figure 1A). Similarly, purple color was developed for synthesis of AuNPs which showed a characteristic peak at $550 \mathrm{~nm}$ (Figure 1B). The rate of synthesis of AuNPs was found to be slow till $1 \mathrm{~h}$. However, after $1 \mathrm{~h}$ a sharp increase in the synthesis rate was evident till $5 \mathrm{~h}$. A similar result was also evident in case of AgNPs. Concentration optimization studies revealed that $3 \mathrm{mM}$ of $\mathrm{AgNO}_{3}$ facilitated maximum rate of synthesis of AgNPs (Figure 2A). At the same time $4 \mathrm{mM}$ of $\mathrm{HAuCl}_{4}$ was found to be optimum for synthesis of AuNPs using GSTE (Figure 2B). In case of temperature optimization studies, high temperature of $50^{\circ} \mathrm{C}$ showed faster and higher rate of nanoparticle synthesis (Figure $3 \mathrm{~A}$ and $3 \mathrm{~B}$ ). 

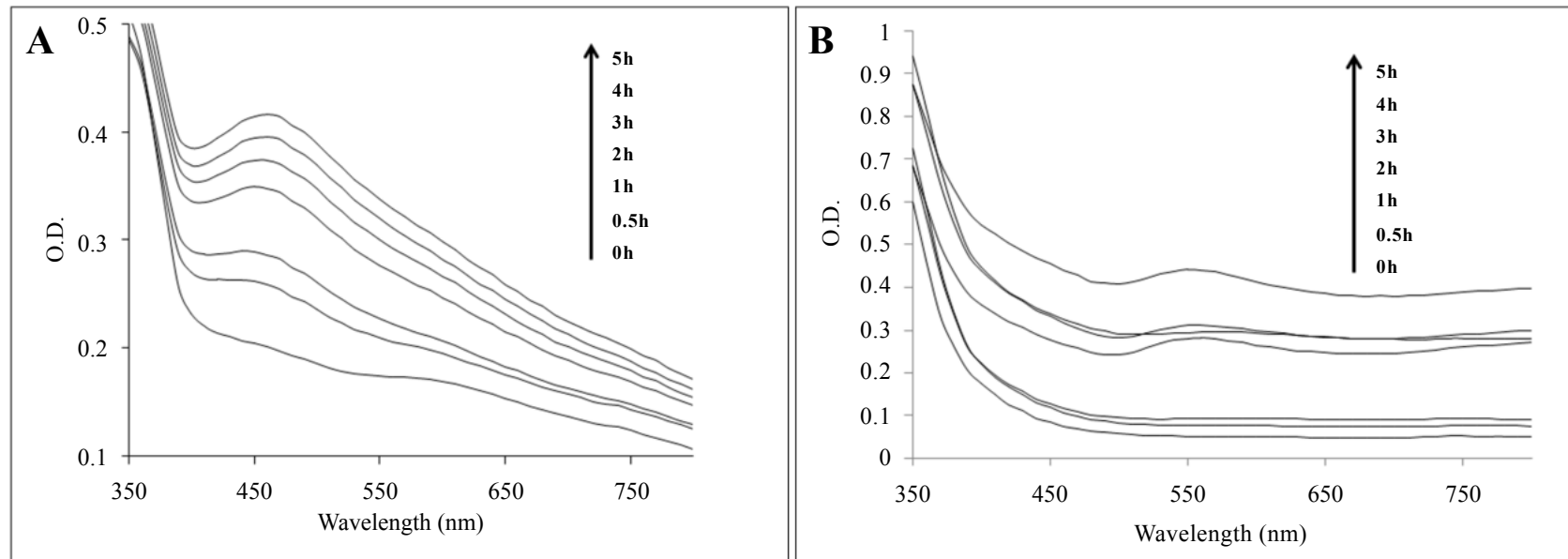

Figure 1: UV-vis spectra recorded as a function of reaction time for nanoparticle formation using $\mathrm{GSTE}$ at $40^{\circ} \mathrm{C}$ with $(\mathrm{A}) 1 \mathrm{mM} \mathrm{AgNO}{ }_{3}$ solution and $(\mathrm{B}) \mathrm{HAuCl}$ solution.
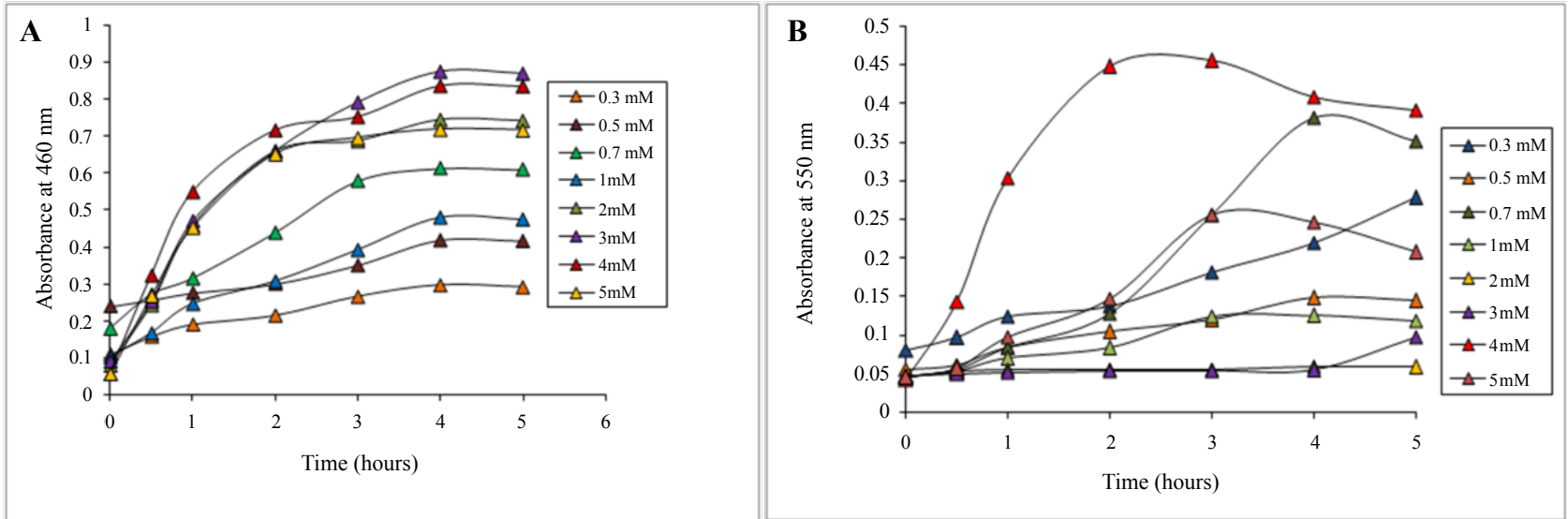

Figure 2: Time course of nanoparticle synthesis using GSTE at $40^{\circ} \mathrm{C}$ with $(\mathrm{A})$ different concentrations of $\mathrm{AgNO}_{3}$ and $(\mathrm{B}) \mathrm{HAuCl}_{4}$.
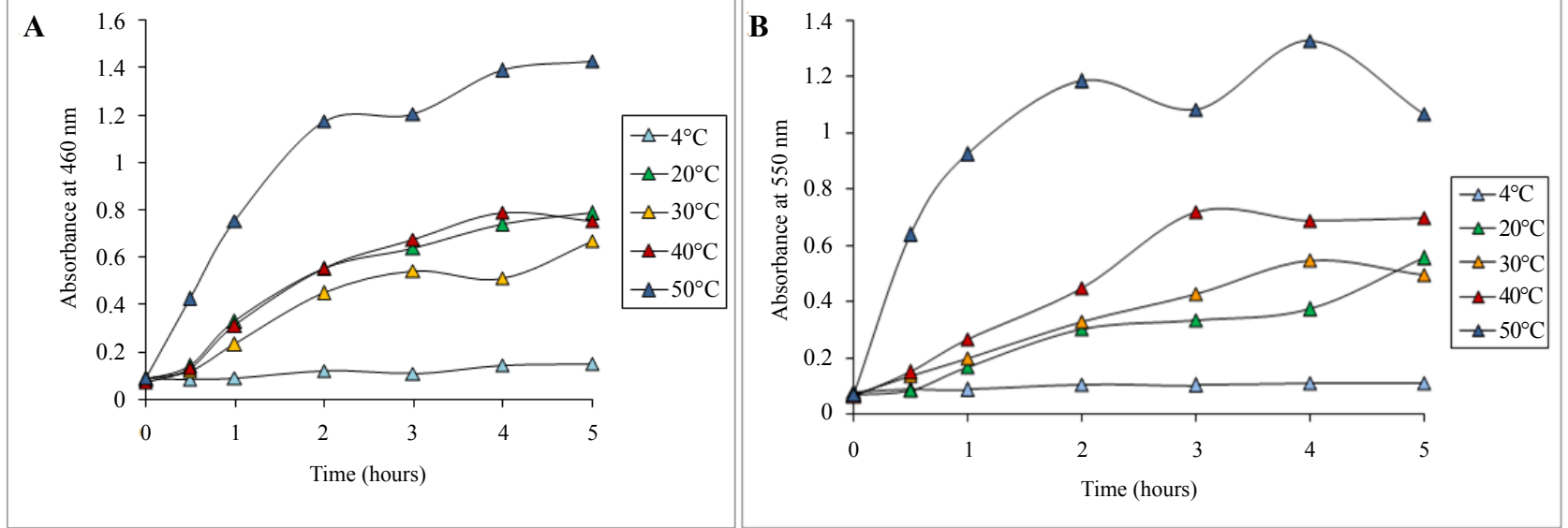

Figure 3: Time course of nanoparticle synthesis using GSTE at different reaction temperatures with (A) $1 \mathrm{mM} \mathrm{AgNO}_{3}$ and (B) $1 \mathrm{mM} \mathrm{HAuCl}_{4}$

\section{HRTEM, EDS, DLS analysis}

HRTEM analysis confirmed the morphological features of the bioreduced nanoparticles. AgNPs formed were spherical in shape with a size ranging from $3 \mathrm{~nm}$ to $20 \mathrm{~nm}$ (Figure $4 \mathrm{~A}$ and $4 \mathrm{~B}$ ). The smaller nanoparticles were found to be well dispersed. Discrete aggregation of smaller nanoparticles in a group of 3 or 4 was also noticed. AuNPs synthesized by GSTE were found to be anisotropic varying from 
Citation: Ghosh S, Harke AN, Chacko MJ, Gurav SP, Joshi KA, et al. (2016) Gloriosa superba Mediated Synthesis of Silver and Gold Nanoparticles for Anticancer Applications. J Nanomed Nanotechnol 7: 390. doi: 10.4172/2157-7439.1000390

spherical to hexagonal in shape. Small equilateral triangle shaped AuNPs were also noticed (Figure 4C and 4D). Nanoparticles were found to be free and well dispersed varying from $20 \mathrm{~nm}$ to $120 \mathrm{~nm}$. EDS analysis exhibiting the signature peaks for elemental $\mathrm{Ag}$ and $\mathrm{Au}$ in the bioreduced nanoparticles confirmed the synthesis of AgNPs and AuNPs, respectively (Figure 5A and 5B). Particle size analysis employing DLS was also in close agreement with the HRTEM measurements (Figure $6 \mathrm{~A}$ and $6 \mathrm{~B})$.

\section{XRD analysis}

The XRD pattern of AuNPs and AgNPs, shown in Figure 7A and 7B were compared with the data released by Joint Committee for Powder Diffraction Standard (JCPDS). The data for AuNPs and AgNPs match with JCPDS data card no. 04-0784 and 04-0783, respectively, confirming the phase formation of the nanoparticles. Lattice planes (111), (200), (220) and (311) for AuNPs and AgNPs were also observed in the XRD pattern. The structures show standard lattice constant to be $4.078 \mathrm{~A}^{0}$

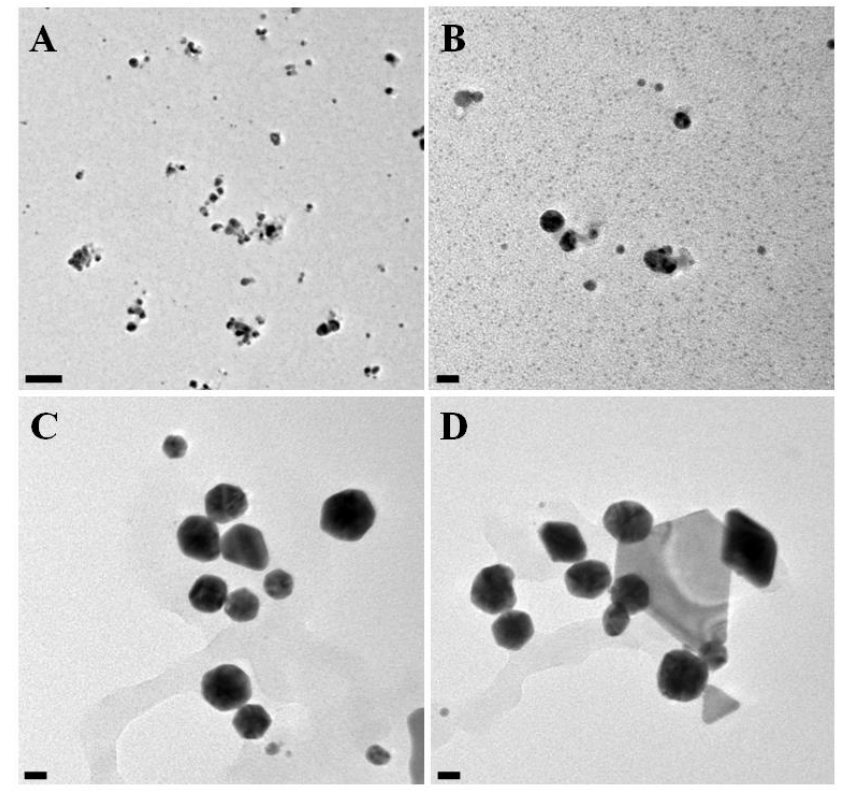

Figure 4: High-resolution transmission electron micrographs of nanoparticles synthesized by GSTE. (A) AgNPs bioreduced by GSTE, inset bar representing of $100 \mathrm{~nm}$; (B) Very small spherical AgNPs bioreduced by GSTE, inset ba representing of $20 \mathrm{~nm}$; (C) Blunt ended hexagonal AuNPs synthesized by GSTE, inset bar representing of $20 \mathrm{~nm}$; (D) Triangular and trapezoid shaped AuNPs synthesized by GSTE, inset bar representing of $20 \mathrm{~nm}$. and $4.086 \mathrm{~A}^{0}$ for AuNPs and AgNPs, respectively. Broad peak in XRD pattern of AgNPs suggest smaller particle size, while the AuNPs show sharp peak, attributed to highly crystalline phase formation. Crystallite size for both the particles was calculated using Scherrer's formula:

$$
D=\frac{0.9 \lambda}{\beta \cos \theta}
$$

where $\mathrm{D}$ is particle size, $\lambda$ is wavelength of $\mathrm{X}$-ray, $\beta$ is full width at half maxima for a peak and $\theta$ is corresponding Bragg angle. The particle size was estimated to be $22 \mathrm{~nm}$ for AgNPs and $25 \mathrm{~nm}$ for AuNPs. This is in good agreement with the particle size obtained from HRTEM images.

\section{FTIR analysis}

GSTE has various components viz. alkaloids, glycosides, steroids, flavonoids, starch, terpenoids, tannins and proteins. In order to understand what group plays key role in reducing the metal salt to the respective nanoparticle, it was necessary to understand the change in the characteristic functional groups of the GSTE, before and after synthesis of nanoparticles. Figure 8 represents the FTIR spectra for (A) GSTE before bioreduction while (B) and (C) represent GSTE after synthesis of AuNPs and AgNPs, respectively. GSTE showed characteristic peaks contributed by its phytochemistry. The broad peak from 3300 to 3500 $\mathrm{cm}^{-1}$ in all the three spectra was attributed to O-H group of phenols/ alcohol, which could be a component of the GSTE. The sharp peak in Figure $8 \mathrm{~A}$ at $1739 \mathrm{~cm}^{-1}$ indicated $\mathrm{C}=\mathrm{O}$ stretch. This could be due to the esters, ketones (flavones) present in GSTE. Other peaks in GSTE at 1337 and $1220 \mathrm{~cm}^{-1}$ could be assigned to the $\mathrm{CH}_{3}$ bending and $\mathrm{C}-\mathrm{O}$ stretching of polyols respectively. The significant shift/change in the GSTE, when utilized in $\mathrm{Ag} / \mathrm{Au}$ nanoparticle formation, was seen at the characteristic peak of $1739 \mathrm{~cm}^{-1}$. This indicates the possible site of interaction of GSTE with the metal salt through the $\mathrm{C}=\mathrm{O}$ group, reducing them into the respective nanoparticles.

\section{Phytochemical analysis}

Biochemical quantification of various phytochemical constituents showed the presence of phenolics, starch, reducing sugars, ascorbic acid and citric acid (Table 1). Very high amount of reducing sugars and ascorbic acid was found to be predominant followed by starch. It is significant to note that GSTE showed the presence of phenolic compounds as well as citric acid, although present in smaller quantity.

\section{GCMS/MS analysis}

GSTE showed the presence of twenty two compounds which might play a role in reduction as well as stabilization process during AgNPs and AuNPs synthesis. The most predominant compounds found in

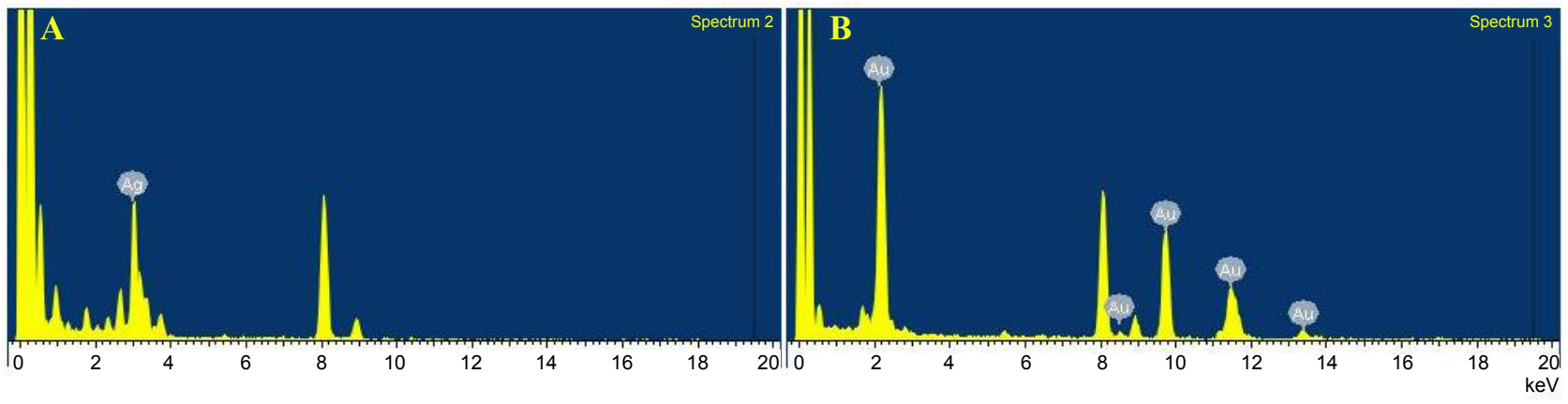

Figure 5: Representative spot EDS profile. (A) AgNPs and (B) AuNPs. 


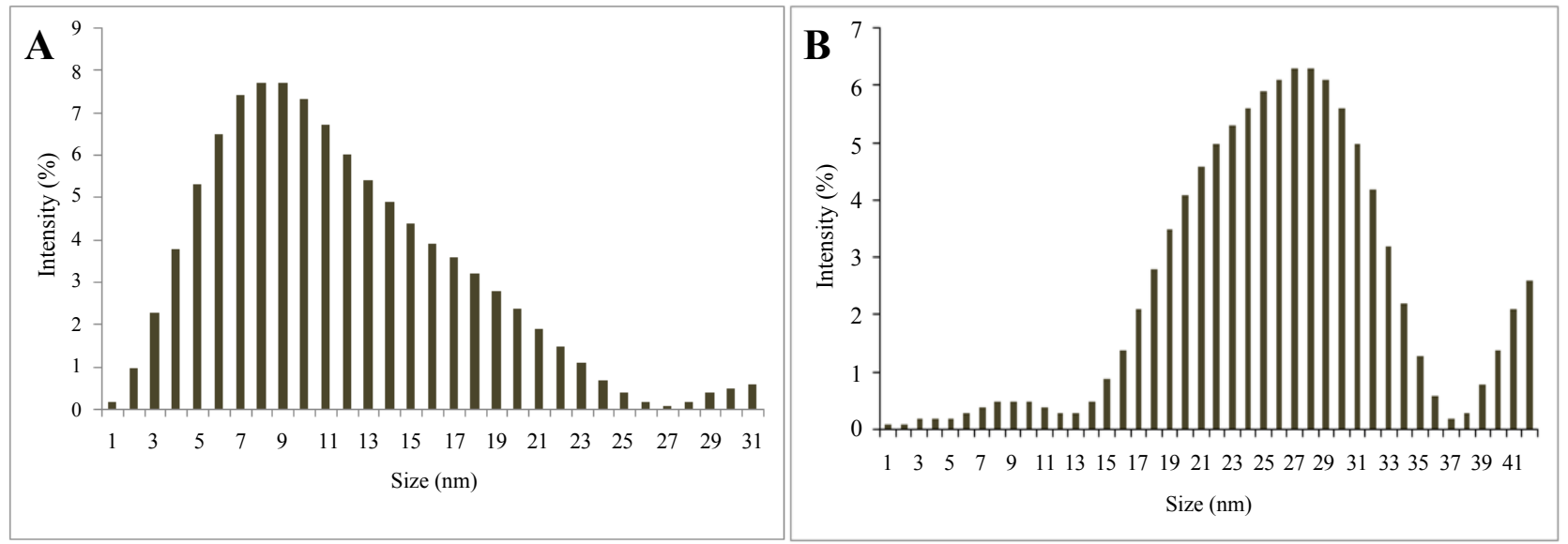

Figure 6: Histogram of size distribution of nanoparticles synthesized by GSTE. (A) AgNPs and (B) AuNPs.

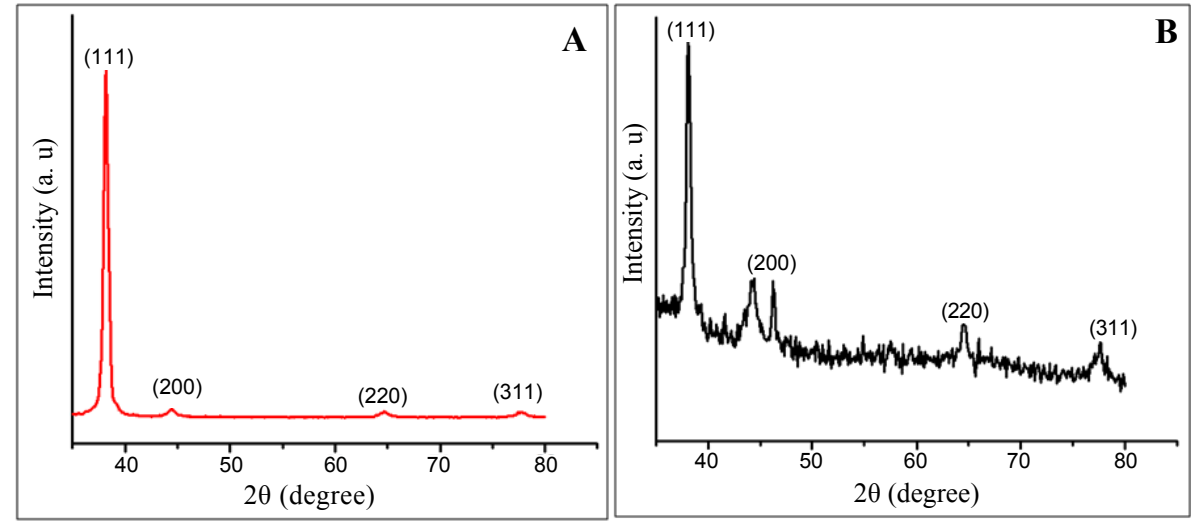

Figure 7: Representative X-ray diffraction profile of thin film AuNPs (A) and AgNPs (B) synthesized by GSTE.

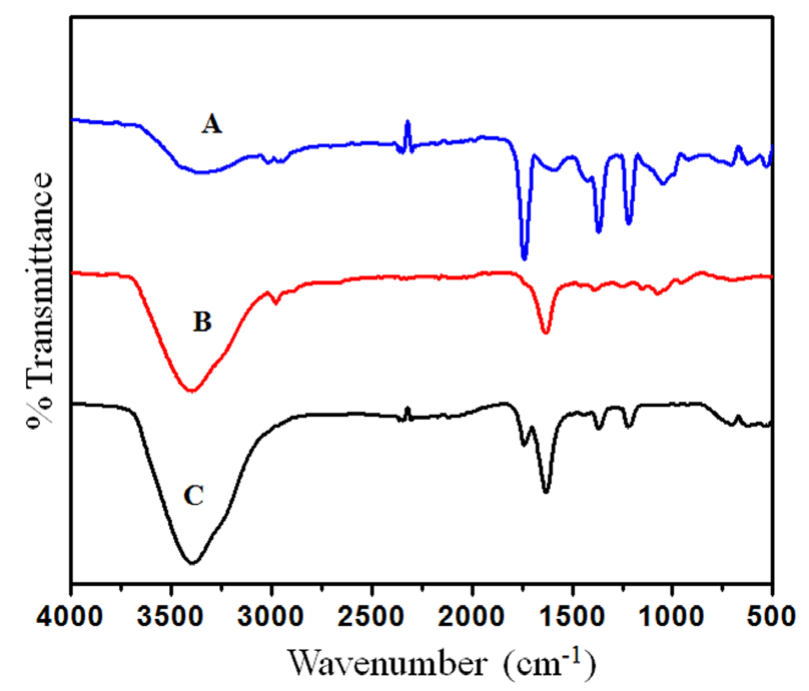

Figure 8: Fourier transform infrared absorption spectra of GSTE before bioreduction (A) and after complete bioreduction of AuNPs (B) and AgNPs (C).

GSTE, as shown in Table 2 were phenol, 3-methoxy- $\left(\mathrm{C}_{7} \mathrm{H}_{8} \mathrm{O}_{2}\right)$, salicyl alcohol $\left(\mathrm{C}_{7} \mathrm{H}_{8} \mathrm{O}_{2}\right)$, benzoic acid, 2-hydroxy-6-methoxy- $\left(\mathrm{C}_{8} \mathrm{H}_{8} \mathrm{O}_{4}\right)$ and asarone $\left(\mathrm{C}_{12} \mathrm{H}_{16} \mathrm{O}_{3}\right)$.

\begin{tabular}{|c|c|c|c|c|c|}
\multirow{2}{*}{ Sample } & \multicolumn{5}{|c|}{ Phytochemicals $(\boldsymbol{\mu g} / \mathbf{m L})$} \\
\cline { 2 - 6 } & $\begin{array}{c}\text { Phenolic } \\
\text { content }\end{array}$ & $\begin{array}{c}\text { Starch } \\
\text { content }\end{array}$ & Reducing sugars & $\begin{array}{c}\text { Ascorbic } \\
\text { acid }\end{array}$ & Citric acid \\
\hline GSTE & 10 & 83.77 & 393.15 & 100 & 6.38 \\
\hline
\end{tabular}

\section{Anticancer activity}

Bioreduced nanoparticles showed variability in their efficiency towards the antiproliferative activity against MCF-7 cells (Figure 9). AgNPs exhibited superior activity up to $42.04 \pm 1.87 \%$ while AuNPs showed least inhibition up to $35.59 \pm 4.1 \%$. However, combination of both AuNPs and AgNPs exhibited a synergistic increase in the antiproliferative activity up to $58.48 \pm 1.71 \%$.

Flow-cytometric analysis supported the data showing more cells were subjected to apoptosis induction in presence of combination of both AuNPs and AgNPs compared to AgNPs, individually (Figure 10).

\section{Confocal microscopic analysis}

Cells treated with AuNPs failed to show any sign of apoptotic induction indicated by failure to uptake both AnnexinV(AV)-FITC and PI which was identical with the untreated control cells (Figure 11). However in case of AgNPs treatment, induction of early apoptosis was evident indicated by AnnexinV (AV)-FITC around the cells. It is important to note that the most prominent apoptosis induction was 
Citation: Ghosh S, Harke AN, Chacko MJ, Gurav SP, Joshi KA, et al. (2016) Gloriosa superba Mediated Synthesis of Silver and Gold Nanoparticles for Anticancer Applications. J Nanomed Nanotechnol 7: 390. doi: 10.4172/2157-7439.1000390

Page 6 of 8

\begin{tabular}{|c|c|c|c|c|}
\hline Sr. No & Name of compounds & Retention time (sec) & Formula & Molecular weight \\
\hline 1 & 2-Undecanethiol, 2-methyl- & 11.81 & $\mathrm{C}_{12} \mathrm{H}_{26} \mathrm{~S}$ & 202 \\
\hline 2 & Benzene, 1,3-dimethoxy- & 15.19 & $\mathrm{C}_{8} \mathrm{H}_{10} \mathrm{O}_{2}$ & 138 \\
\hline 3 & Hexadecane, 1,1-bis(dodecyloxy)- & 15.99 & $\mathrm{C}_{40} \mathrm{H}_{82} \mathrm{O}_{2}$ & 594 \\
\hline 4 & Tetradecane, 2,6,10-trimethyl- & 16.28 & $\mathrm{C}_{17} \mathrm{H}_{36}$ & 240 \\
\hline 5 & 2-Ethoxybenzyl alcohol & 16.72 & $\mathrm{C}_{9} \mathrm{H}_{12} \mathrm{O}_{2}$ & 152 \\
\hline 6 & Phenol, 3-methoxy- & 17.70 & $\mathrm{C}_{7} \mathrm{H}_{8} \mathrm{O}_{2}$ & 124 \\
\hline 7 & Salicyl Alcohol & 19.10 & $\mathrm{C}_{7} \mathrm{H}_{8} \mathrm{O}_{2}$ & 124 \\
\hline 8 & Isotridecanol- & 19.74 & $\mathrm{C}_{13} \mathrm{H}_{28} \mathrm{O}$ & 200 \\
\hline 9 & 2-Isopropyl-5-methyl-1-heptanol & 20.30 & $\mathrm{C}_{11} \mathrm{H}_{24} \mathrm{O}$ & 172 \\
\hline 10 & 1,2,4-Trimethoxybenzene & 22.12 & $\mathrm{C}_{9} \mathrm{H}_{12} \mathrm{O}_{3}$ & 168 \\
\hline 11 & Hexadecane, 1,1-bis(dodecyloxy)- & 22.76 & $\mathrm{C}_{40} \mathrm{H}_{82} \mathrm{O}_{2}$ & 594 \\
\hline 12 & Tetradecane & 23.02 & $\mathrm{C}_{14} \mathrm{H}_{30}$ & 198 \\
\hline 13 & Disulfide, di-tert-dodecyl & 25.32 & $\mathrm{C}_{24} \mathrm{H}_{50} \mathrm{~S}_{2}$ & 402 \\
\hline 14 & Phenol, 2,4-bis(1,1-dimethylethyl)- & 26.56 & $\mathrm{C}_{14} \mathrm{H}_{22} \mathrm{O}$ & 206 \\
\hline 15 & Benzoic acid, 2-hydroxy-6-methoxy- & 27.32 & $\mathrm{C}_{8} \mathrm{H}_{8} \mathrm{O}_{4}$ & 168 \\
\hline 16 & Asarone & 27.60 & $\mathrm{C}_{12} \mathrm{H}_{16} \mathrm{O}_{3}$ & 208 \\
\hline 17 & Erucic acid & 28.88 & $\mathrm{C}_{22} \mathrm{H}_{42} \mathrm{O}_{2}$ & 338 \\
\hline 18 & 3-Chloropropionic acid, heptadecyl ester & 31.69 & $\mathrm{C}_{20} \mathrm{H}_{39} \mathrm{ClO}_{2}$ & 346 \\
\hline 19 & 6-(1-Adamantylamino)-2,4,5-trichloronicotinonitrile & 32.75 & $\mathrm{C}_{16} \mathrm{H}_{16} \mathrm{Cl}_{3} \mathrm{~N}_{3}$ & 355 \\
\hline 20 & Octadecane, 3-ethyl-5-(2-ethylbutyl)- & 34.55 & $\mathrm{C}_{26} \mathrm{H}_{54}$ & 366 \\
\hline 21 & 2-Ethyl-3-methyl-6,7-dihydro-5H-cyclopenta[b]pyridine-4-amine & 34.84 & $\mathrm{C}_{11} \mathrm{H}_{16} \mathrm{~N}_{2}$ & 176 \\
\hline 22 & Decanoic acid, octadecyl ester & 35.51 & $\mathrm{C}_{28} \mathrm{H}_{56} \mathrm{O}_{2}$ & 424 \\
\hline
\end{tabular}

Table 2: Main compounds detected by GCMS/MS

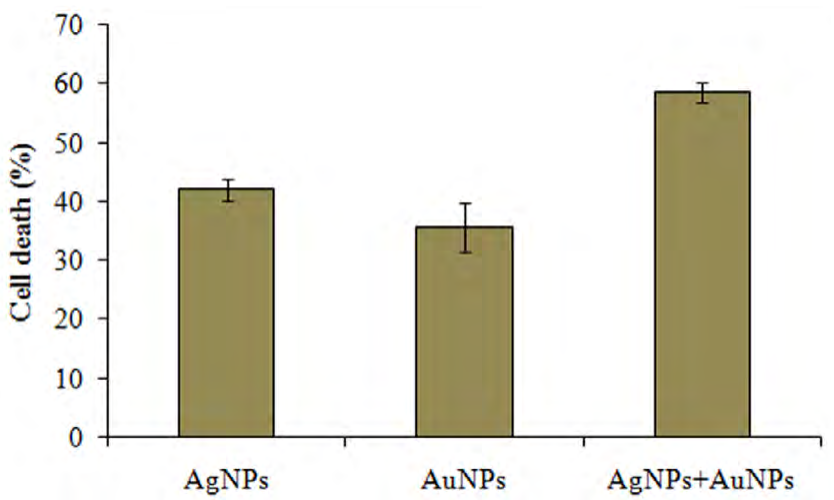

Figure 9: Antiproliferative activity of AgNPs, AuNPs, and AgNPs combined with AuNPs against MCF-7 cells. The data are expressed as a percentage of the control MTT reduction (always taken as $100 \%$ ) and represent the average \pm SEM $(n=3)$.
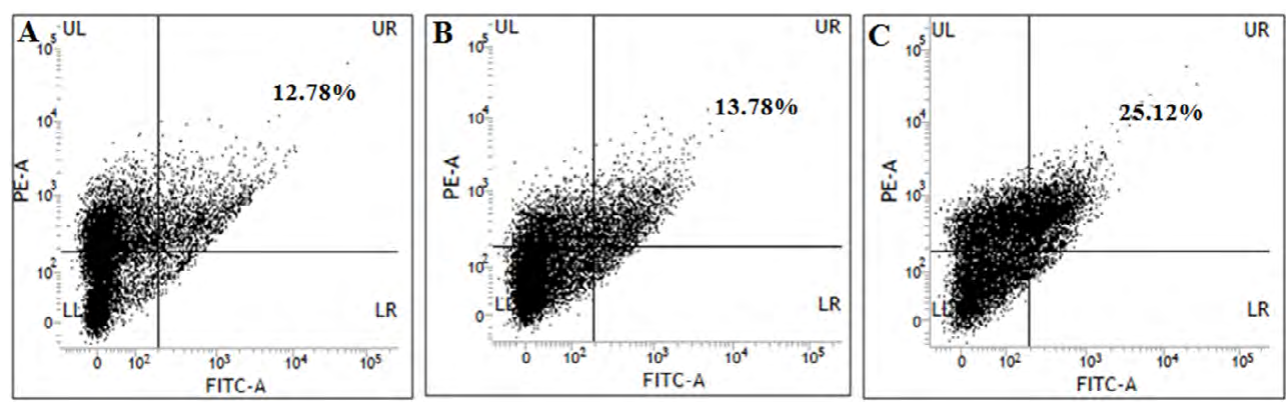

Figure 10: Flow cytometric analysis of phosphatidylserine externalization (annexin $\mathrm{V}$ binding) and cell membrane integrity (PI staining) for MCF-7 cells treated with AgNPs and combination of AgNPs and AuNPs for 48 hours. Notes: The dual parametric dot plots combining annexin V-FITC and PI fluorescence show the viable cell population (lower left quadrant, annexin $\mathrm{V}$ - $\mathrm{PI}$-), the early apoptotic cells (lower right quadrant, annexin $\mathrm{V}+\mathrm{PI}$-), and the late apoptotic cells (upper right quadrant, annexin $\mathrm{V}+\mathrm{PI}+$ ). (A) Untreatment cells; (B) treatment with AgNPs; (C) treatment with AgNPs and AuNPs together.

achieved by treatment with AgNPs and AuNPs together where the cells were found to be dual positive with AnnexinV(AV)-FITC binding at the surface while PI was found to get internalized.

\section{Discussion}

Herein we have demonstrated the efficiency of Gloriosa superba 

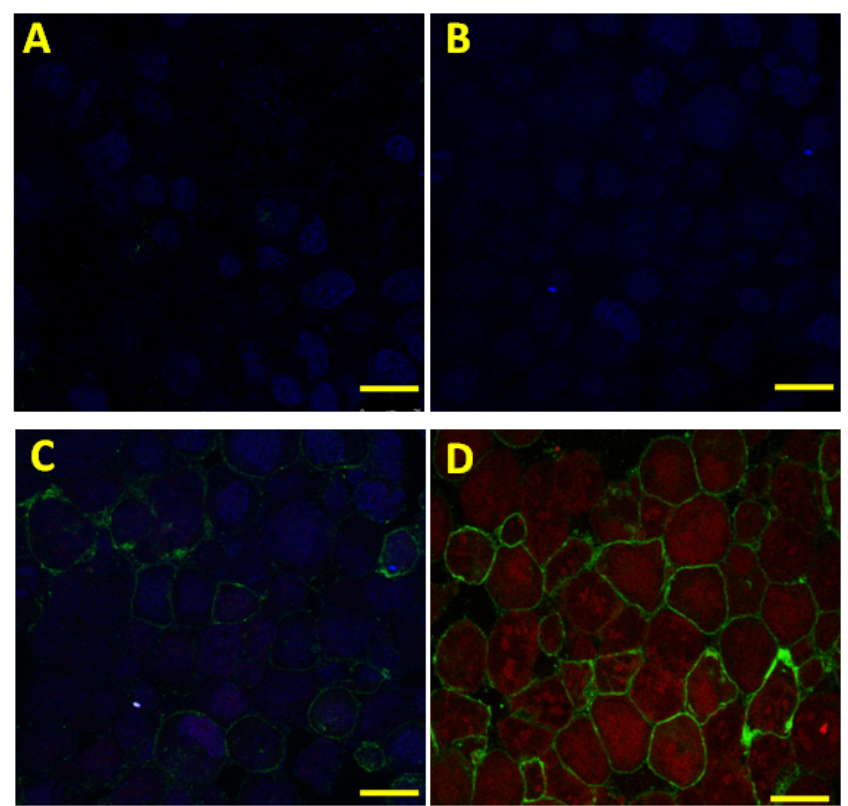

Figure 11: Apoptosis: MCF-7 cells seeded on coverslips were treated with 50 $\mathrm{ug} / \mathrm{ml}$ of AgNPs, AuNPs and AgNPs together with AuNPs for $48 \mathrm{~h}$, and then stained for Annexin V-FITC and PI. (A) Untreated control cells; (B) Cells treated with AuNPs; (C) Cells treated with AgNPs and (D) Cells treated with both AgNPs and AuNPs. Inset scale bar represents $25 \mu \mathrm{m}$.

tuber extract to synthesize both AuNPs and AgNPs. Synthesis of AgNPs was confirmed by the development of intense brown color while a ruby red color was observed for gold. Similar observations were confirmed in our previous reports where Dioscorea bulbifera tuber extract synthesized AuNPs and AgNPs [6,7]. G. superba is reported to contain various phytochemicals like alkaloid, flavonoids, glycosides, phenols, saponins, steroids, tannin and terpenoids [18]. Flavonoids and phenolics play a key role in the bioreduction of metal ions to nanoparticles in the reaction mixture. Reducing sugars are also responsible for biological synthesis of metal nanoparticles using plant extracts. Further the presence of starch is also reported in G. superba which might play a key role as capping agent and thereby stabilizing the bioreduced nanoparticles by prevention of agglomeration [6,18]. Synthesis of AuNPs and AgNPs was found to be completed at $5 \mathrm{~h}$ which was faster as compared to the earlier reports using Aloe vera and Acalypha indica leaf extract which took $24 \mathrm{~h}$ and $8 \mathrm{~h}$, respectively for complete synthesis $[19,20]$. Higher temperature was found to facilitate the synthesis of nanoparticles which is in well agreement with our previous report on Gnidia glauca flower [21,22]. Similarly, even concentration of $\mathrm{AgNO}_{3}$ and $\mathrm{HAuCl}_{4}$ influenced the rate of synthesis to a significant level that was confirmed by earlier reports as well [20]. HRTEM analysis revealed the dominance of nanospheres in case of AgNPs while more pronounced anisotropy was found in case of AuNPs. Similar results were also seen for synthesis of AgNPs and AuNPs using Adiantum philippense L. frond and Cinnamomum camphora leaf [9,23]. Energy dispersive spectra and XRD confirmed the purity and crystallinity of the bioreduced AuNPs and AgNPs [24,25]. FTIR spectra gave insight to the changes in phytochemistry leading to the synthesis AuNPs and AgNPs [26]. Bioreduced AgNPs showed more potent antiproliferative activity against MCF-7 cell lines. AgNPs synthesized by GSTE were superior apoptotic inducers as compared to AuNPs. However, when both AuNPs and AgNPs were combined together, the apoptotic induction was found to be synergistically increased. Our results are well in agreement with the earlier report on AgNPs synthesized by Citrullus colocynthis exhibiting efficient anticancer activity as well against human cancer cell lines of colon (HCT-116), breast (MCF-7), liver (Hep-G2) and intestine (Caco-2) confirming promises of biogenic nanoparticles in the treatment and management of cancer [27]. Induction of apoptosis was confirmed by dual staining using Annexin V-FITC and PI. As confirmed in confocal micrographs Annexin V-FITC staining was positive for both AgNPs treated and combined AgNPs and AuNPs treated cells. Binding of Annexin V-FITC is highly specific to externalization of phosphotidylserine from the internal to the outer surface of cell membrane, which is considered to be a hallmark of early stages of apoptosis. At the same time internalization of PI marks the extensive damage to cell membrane leading to apoptotic effects rather than necrosis which was seen to be more prominent when cells were treated with both AgNPs and AuNPs. In view of the background it can be concluded that the combination of bioreduced AgNPs and AuNPs exhibits promises as novel anticancer agents.

\section{Conclusion}

This is the first report on rapid and efficient synthesis of novel AuNPs and AgNPs using traditional medicinal plant G. superba within $5 \mathrm{~h}$. AgNPs were found to be smaller and mostly spherical while AuNPs showed anisotropy. Diverse phytochemicals present in GSTE might play a key role in both synthesis and stabilization of the bioreduced nanoparticles. AgNPs showed more potent anti-cancer activity which could be synergistic enhancement by supplementation of AuNPs. The mechanism behind the anticancer activity was determined to be by induction of apoptosis. Hereby, it is of utmost scientific rationale to design and explore the combined effects of GSTE synthesized AgNPs and AuNPs as novel biomedicine for triggering induction of apoptosis for treatment and management of cancer.

\section{Acknowledgment}

The authors acknowledge the help extended for the use of TEM and HRTEM facilities in Chemical Engineering and CRNTS funded by the DST through Nanomission and IRPHA schemes and Board of College and University Development (BCUD), Savitribai Phule Pune University for research grant (11SCI001810). Dr. Sougata Ghosh thanks Council of Scientific and Industrial Research (CSIR, Government of India) for Senior Research Fellowship (09/137(0516)/2012-EMR-I) and DST INSPIRE. Dr. Geetanjali Tomar thanks DST INSPIRE for the faculty position and the research grant (IFA13 LSBM73 and GOI-E-161(2), respectively).

\section{References}

1. Ghosh S, More P, Nitnavare R, Jagtap S, Chippalkatti R, et al. (2015) Antidiabetic and antioxidant properties of copper nanoparticles synthesized by medicinal plant Dioscorea bulbifera. J Nanomed Nanotechnol S6: 007.

2. Singh R, Shedbalkar UU, Wadhwani SA, Chopade BA (2015) Bacteriagenic silver nanoparticles: synthesis, mechanism, and applications. Appl Microbiol Biotechnol 99: 4579-4593.

3. Shedbalkar U, Singh R, Wadhwani S, Gaidhani S, Chopade BA (2014) Microbial synthesis of gold nanoparticles: current status and future prospects. Adv Colloid Interface Sci 209: 40-48.

4. Ghosh S, Nitnavare R, Dewle A, Tomar GB, Chippalkatti R, et al. (2015) Novel platinum-palladium bimetallic nanoparticles synthesized by Dioscorea bulbifera: anticancer and antioxidant activities. Int J Nanomed10: 7477-7490.

5. Ghosh S, Jagtap S, More P, Shete UJ, Maheshwari NO, et al. (2015) Dioscorea bulbifera mediated synthesis of novel AucoreAgshell nanoparticles with potent antibiofilm and antileishmanial activity. J Nanomater.

6. Ghosh S, Patil S, Ahire M, Kitture R, Kale S, et al. (2012) Synthesis of silver nanoparticles using Dioscorea bulbifera tuber extract and evaluation of its synergistic potential in combination with antimicrobial agents. Int $\mathrm{J}$ Nanomedicine 7: 483-496.

7. Salunke G R, Ghosh S, Kumar RJS, Khade S, Vashisth P, et al. (2014) Rapid 
Citation: Ghosh S, Harke AN, Chacko MJ, Gurav SP, Joshi KA, et al. (2016) Gloriosa superba Mediated Synthesis of Silver and Gold Nanoparticles for Anticancer Applications. J Nanomed Nanotechnol 7: 390. doi: 10.4172/2157-7439.1000390

efficient synthesis and characterization od AgNPs, AuNPs and AgAuNPs from a medicinal plant, Plumbago zeylanica and their application in biofilm control. Int J Nanomedicine 9: 2635-2653.

8. Sant DG, Gujarathi TR, Harne SR, Ghosh S, Kitture R, et al. (2013) Adiantum philippense L. frond assisted rapid green synthesis of gold and silver nanoparticles. Journal of Nanoparticles.

9. Wadhwani SA, Shedbalkar UU, Singh R, Chopade BA, et al. (2016) Biogenic selenium nanoparticles: current status and future prospects. Appl Microbio Biotechnol 100: 2555-2566.

10. Singh R, Nawale LU, Arkile M, Shedbalkar UU, Wadhwani SA, et al. (2015) Chemical and biological metal nanoparticles as antimycobacterial agents: $A$ comparative study. Int J Antimicrob Agents 46: 183-188.

11. Gaidhani SV, Yeshvekar RK, Shedbalkar UU, Bellare JH, Chopade BA (2014) Bio-reduction of hexachloroplatinic acid to platinum nanoparticles employing Acinetobacter calcoaceticus. Process Biochem 49: 2313-2319.

12. Wadhwani SA, Shedbalkar UU, Singh R, Karve MS, Chopade BA (2014) Novel polyhedral gold nanoparticles: green synthesis, optimization and characterization by environmental isolate of Acinetobacter sp. SW30. World J Microb Biotechnol 30: 2723-2731.

13. Gaidhani S, Singh R, Singh D, Patel U, Chopade BA (2013) Biofilm disruption activity of silver nanoparticles synthesized by Acinetobacter calcoaceticus PUCM 1005. Mater Lett 108: 324-327.

14. Singh R, Wagh P, Wadhwani S, Gaidhani S, Kumbhar A, Bellare J, et al. (2013) Synthesis, optimization, and characterization of silver nanoparticles from Acinetobacter calcoaceticus and their enhanced antibacterial activity when combined with antibiotics. Int J Nanomed. 8: 4277-4290.

15. Ade R, Rai M (2009) Review: Current Advances in Gloriosa superba L. Biodiversitas 10: 210-214.

16. Senthilkumar M (2013) Phytochemical screening of Gloriosa superba L. from different geographical positions. Int J Sci Res Pub 3: 1-5.

17. Chandran SP, Chaudhary M, Pasricha R, Ahmad A, Sastry M (2006) Synthesis of gold nanotriangles and silver nanoparticles using Aloe vera plant extract. Biotechnol Prog 22: 577-583

18. Krishnaraj C, Ramachandran R, Mohan K, Kalaichelvan PT (2012) Optimization for rapid synthesis of silver nanoparticles and its effect on phytopathogenic fungi. Spectrochim Acta A Mol Biomol Spectrosc 93: 95-99.

19. Ghosh S, Patil S, Ahire M, Kitture R, Gurav DD, et al. (2012) Gnidia glauca flower extract mediated synthesis of gold nanoparticles and evaluation of its chemocatalytic potential. J Nanobiotechnology 10: 17.

20. Huang J, Li Q, Sun D, et al. (2007) Biosynthesis of silver and gold nanoparticles by novel sundried Cinnanonum camphora leaf. Nanotechnology. 18:105104105114.

21. Bankar A, Joshi B, Kumar AR, Zinjarde S (2010) Banana peel extract mediated novel route for the synthesis of silver nanoparticles. Colloids and Surfaces A: Physicochem. Eng. Aspects 368: 58-63.

22. Bankar A, Joshi B, Kumar AR, Zinjarde S (2010) Banana peel extract mediated synthesis of gold nanoparticles. Colloids Surf B Biointerfaces 80: 45-50.

23. Zhan G, Huang J, Lin L, Lin W, Emmanuel K, Li Q (2011) Synthesis of gold nanoparticles by Cacumen platycladi leaf extract and its simulated solution: toward the plant-mediated biosynthetic mechanism. J Nanopart Res 13: 4957.

24. Shawkey AM, Rabeh MA, Abdulall AK, Abdellatif AO (2013) Green nanotechnology: Anticancer activity of silver nanoparticles using Citrullus colocynthis aqueous extracts. Adv Life Sci Technol 13:60-70.

25. Ghosh S, More P, Derle A, Kitture R, Kale T, et al. (2015) Diosgenin Functionalized Iron Oxide Nanoparticles as Novel Nanomaterial Against Breast Cancer. J Nanosci Nanotechnol 15: 9464-9472.

26. Sontakke VA, Kate AN, Ghosh S, More P, Gonnade R, et al. (2015) Synthesis, DNA interaction and anticancer activity of 2-anthryl substituted benzimidazole derivatives. New J Chem 39: 4882-4890.

27. Mallick A, More P, Ghosh S, Chippalkatti R, et al. (2015) Dual drug conjugated nanoparticle for simultaneous targeting of mitochondria and nucleus in cancer cells. ACS Appl Mater Interfaces 7: 7584-7598. 